\title{
Terapi ARV Meningkatkan Kadar IL-17 Serum pada Pasien HIV
}

\section{ARV Treatment Increase IL-17 Serum Level in HIV Patients}

\author{
Hendrik Wahyudi, Didi Candradikusuma, Niniek Budiarti B, Gatoet Ismanoe
}

Laboratorium IImu Penyakit Dalam Rumah Sakit Umum Dr. Saiful Anwar Malang

\begin{abstract}
ABSTRAK
Penurunan jumlah atau fungsi Th-17 mempengaruhi produksi IL-17 sehingga virus HIV lebih mudah mengalami replikasi. Pemberiaan ARV yang dapat menekan replikasi virus HIV diharapkan dapat memperbaiki produksi IL-17 dan menyebabkan pulihnya fungsi Th-17. Penelitian dilakukan untuk mengetahui rerata kadar IL-17 serum pada pasien HIV sebelum dan setelah 3 bulan mendapat terapi ARV. Survei pre dan post tes dilakukan pada pasien infeksi HIV yang baru terdiagnosa di RSU Dr. Saiful Anwar-Malang. Diagnosa HIV berdasarkan kriteria WHO, dan IL-17 serum diukur dengan metode ELISA. Hitung limfosit T-CD4 absolut menggunakan metode flowcytometry. Analisa statistik yang digunakan untuk komparasi numerik adalah uji $t$ berpasangan dan analisa korelasi menggunakan uji Spearman. Kadar IL-17 serum

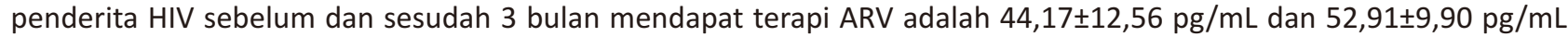
$(p=0,005)$. Hitung sel limfosit T-CD4 absolut sebelum dan sesudah 3 bulan mendapat terapi ARV adalah 69,41 $\pm 95,06$ cells $/ \mathrm{mL}$ dan $180,72 \pm 73,15$ cells $/ \mathrm{mL}(\mathrm{p}=0,000)$. Kadar IL-17 serum didapatkan tidak berkorelasi dengan hitung sel T-CD4 absolut ( $p=0,914, r=-0,024)$. Dapat disimpulkan kadar IL-17 serum dan CD4 penderita HIV setelah 3 bulan mendapat terapi ARV lebih tinggi dibandingkan sebelum mendapat terapi ARV, namun, kadar IL-17 tidak berhubungan dengan hitung sel limfosit T-CD4.
\end{abstract}

Kata Kunci: CD4, infeksi HIV, IL-17 serum, Th-17

\section{ABSTRACT}

The decreasing of Th-17 number or function affecting IL-17 production cause HIV virus replicate easier. With the ARV that suppress HIV virus replication, it is expected that IL-17 production can be repaired and TH-17 function can be recovered. Research conducted to discover the average of IL-17 serum on HIV patients before and after 3 months of ARV therapy. Pre and post test survey was conducted on newly diagnosed HIV patients in Saiful Anwar General Hospital Malang. Diagnosis of HIV infection was based on WHO criteria and IL-17 serum measured with ELISA method, meanwhile CD4-Lymphocyte T counting using flowcytometry. Statistical analysis of numeric comparison using paired Ttest and correlation analysis using Spearman test. IL-17 serum level of HIV patient before and 3 months after ARV therapy was 44,17 $\pm 12,56 \mathrm{pg} / \mathrm{mL}$ and

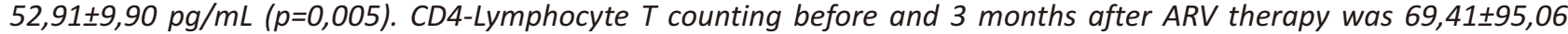
cells $/ \mathrm{mL}$ and $180,72 \pm 73,15$ cells $/ \mathrm{mL}(p=0,000)$. It is found that IL-17 serum level has no correlation with absolute CD4Lymphocyte T counting ( $p=0,914, r=-0,024)$. It can be concluded that IL-17 serum and CD4 of HIV patients after 3 months of $A R V$ was higher compared to before therapy, but IL-17 serum level has no correlation with CD4-Lymphocyte T counting.

Keywords: CD4, HIV infection, interleukin 17 serum, Th17

Jurnal Kedokteran Brawijaya, Vol. 27, No. 4, Agustus 2013; Korespondensi: Hendrik Wahyudi. Laboratorium Ilmu Penyakit Dalam Rumah Sakit Umum Dr. Saiful Anwar Malang, Jl. Jaksa Agung Suprapto No. 2 Malang Tel. (0341) 362101, 357663 Email: interne_rssa@yahoo.com 


\section{PENDAHULUAN}

United Nations and AIDS (UNAIDS) pada Global HIV dan AIDS Epidemik, November 2010, melaporkan terdapat 33,3 juta penderita Human Immunodeficiency Virus (HIV)/Acquired Immunodeficiency Syndrom (AIDS) di seluruh dunia (1). Penurunan jumlah limfosit T-CD4 merupakan karakteristik utama dari infeksi HIV (2). Pada fase akut infeksi HIV, terjadi secara cepat, replikasi virus dan penurunan limfosit T-CD4. Pada fase kronik, HIV juga menyebabkan terganggunya sistem imun dan kerusakan sebagian besar limfosit T-CD4 $(3,4)$. Penurunan sistem imun secara progresif ini menyebabkan kegagalan sistem imun, yang ditandai dengan perburukan klinis penderita dan terjadinya infeksi oportunistik (5).

Limfosit Th-17, sebagai subset dari limfosit T-CD4 (6-9), pada studi-studi terbaru disebutkan mengalami penurunan selama infeksi HIV dan mungkin berhubungan dengan progresivitas HIV. Pada infeksi HIV, sel Th-17 terdeplesi selektif pada kompartemen limfosit gastrointestinal (gut associated lymphoid tissue, GALT). Hal ini menyebabkan integritas mukosa dapat ditembus dan terjadi translokasi bakteri melewati barrier epithelial, yang mengakibatkan aktifasi imun kronis seiring progresifitas penyakit (10-12). Sel Th-17 ini menghasilkan IL-17, yang merupakan sitokin proinflamasi dan berperan penting dalam sistem pertahanan tubuh melawan infeksi mikroba, bakteri ekstra selular dan jamur (5-8). Penurunan IL-17 akan menyebabkan berkurangnya kemampuan sel host dalam melawan bakteri, meningkatkan kerusakan mukosa barrier, aktivasi imun lokal, percepatan replikasi virus dan akhirnya terjadi kegagalan sistem imun (5-7).

Pemberian antiretroviral (ARV) dapat menekan replikasi virus HIV, menurunkan viral load, mencegah perburukan tanda dan gejala HIV, memperlambat progresivitas penyakit, menurunkan kejadian infeksi oportunistik dan tumor, melindungi limfosit T-CD4 dari kerusakan, memperbaiki sistem imun dan mungkin dapat meningkatkan jumlah sel Th 17 913-14). Berbagai penelitian telah dilakukan untuk lebih memahami peran sistem imun, Th17, interleukin 17 dan terapi ARV pada penderita HIV. Namun studi yang ada belum menyimpulkan kadar serum IL-17 yang berpengaruh terhadap pasien infeksi HIV/AIDS. Dalam penelitian ini dilakukan evaluasi kadar serum IL-17 penderita HIV baru sebelum dan setelah 3 bulan mendapat terapi ARV serta hubungannya dengan hitung sel limfosit T-CD4 absolut.

\section{METODE}

Rancangan penelitian menggunakan desain survey pre dan post test, pada populasi terjangkau penderita baru infeksi HIV/AIDS. Penelitian dilakukan di unit rawat jalan dan unit rawat inap Penyakit Tropik dan Infeksi RSU Dr. Saiful Anwar Malang, mulai 1 November 2011 hingga 30 April 2012. Subjek penelitian direkrut dengan metode sampling konsekutif pada penderita HIV yang memenuhi kriteria inklusi dan eksklusi setelah mendapatkan penjelasan dan menandatangani informed consent. Diagnosis infeksi HIV ditegakkan berdasarkan kriteria WHO, secara klinis dan laboratorium, dengan dilakukan pemeriksaan antibodi HIV dengan tiga metode ELISA yang berbeda. Terapi ARV yang diberikan sesuai dengan standar terapi WHO.

Penelitian ini telah disetujui oleh Komite Etik Penelitian Kesehatan RSU Dr. Saiful Anwar Malang. Selama periode penelitian didapatkan 22 penderita infeksi HIV sesuai jumlah perhitungan sampel, yang memenuhi kriteria inklusi, meliputi penderita HIV yang baru terdiagnosa dan belum mendapat terapi ARV, berusia dewasa (21-60 tahun). Kriteria eksklusi meliputi kondisi yang mempengaruhi status imun pasien, yaitu dalam pengobatan kortikosteroid, keganasan yang tidak termasuk dalam stadium klinis IV HIV menurut WHO, diabetes mellitus, gagal ginjal kronis, malnutrisi berat dan wasting syndrome. Sampel serum berasal dari darah vena sebanyak $3 \mathrm{ml}$ dalam tabung EDTA. Untuk pemeriksaan kadar serum IL-17 menggunakan metode ELISA (eBioscience Platinum IL-17 A/F). Hitung limfosit T-CD4 absolut menggunakan metode flowcytometry. Parameter lain yang diukur meliputi total lymfosit count (TLC), hemoglobin, indeks masa tubuh (IMT), albumin.

Data klinis dan hasil laboratorium subjek penelitian ditampilkan sebagai karakteristik dasar deskriptif. Data kuantitatif ditampilkan dalam bentuk rerata \pm SD. Analisa statistik yang digunakan untuk komparasi numerik kadar IL-17 serum adalah uji $t$ berpasangan, dengan interval kepercayaan $95 \%$ dan dianggap bermakna bila nilai $p<0,05$. Analisis korelasi kadar IL-17 serum dengan hitung limfosit T-CD4 absolut dilakukan menggunakan koefisien korelasi Spearman. Semua data dianalisa menggunakan program SPSS for Windows release 15.0

\section{HASIL}

Hasil penelitian (Tabel 1) menggambarkan subjek penelitian terdiri dari 12 laki-laki (55\%) dan 10 wanita (45\%) yang berkunjung di unit rawat jalan atau yang menjalani rawat inap di ruang tropik infeksi Rumah Sakit Umum Dr. Saiful Anwar Malang. Berdasarkan golongan usia penderita, 10 orang berusia 21-30 tahun, 10 orang berusia 31-40 tahun dan 2 orang termasuk kategori umur 41-50 tahun.

Tabel 1. Karakteristik subjek penelitian

\begin{tabular}{lc}
\hline Karakteristik Subjek & Jumlah \\
\hline Jenis Kelamin & $12(55 \%)$ \\
Pria & $10(45 \%)$ \\
Wanita & \\
Kelompok Usia & $10(45 \%)$ \\
$21-30$ tahun & $10(45 \%)$ \\
$31-40$ tahun & $2(10 \%)$ \\
$>40$ tahun & \\
Faktor Risiko & $6(27 \%)$ \\
IDU & $16(73 \%)$ \\
Hubungan Seksual & \\
Stadium Klinis WHO & $3(14 \%)$ \\
I & $2(8 \%)$ \\
II & $14(64 \%)$ \\
III & $3(14 \%)$ \\
IV & \\
Infeksi oportunistik & $13(59 \%)$ \\
Candidiasis & $9(40 \%)$ \\
TB & $5(22 \%)$ \\
Candidiasis+TB & $1(5 \%)$ \\
Toksoplasmosis & $1(5 \%)$ \\
Hepatitis B & $1(5 \%)$ \\
Hepatitis C &
\end{tabular}

Sumber penularan HIV pada sampel penelitian ini adalah melalui penggunaan jarum suntik bersama antar IDU 6 
orang (27\%) dan melalui hubungan seksual 16 orang (73\%). Berdasarkan stadium klinis HIV/AIDS WHO tahun 2010, penderita yang termasuk dalam stadium I sebanyak 3 orang (14\%), stadium II sebanyak 2 orang ( $8 \%)$, stadium III sebanyak 14 orang (64\%) dan stadium IV sebanyak 3 orang (14\%). Semua penderita memiliki jumlah limfosit T$\mathrm{CD} 4 \leq 350 \mathrm{sel} / \mathrm{mL}$. Jumlah penderita yang memiliki jumlah limfosit total (TLC) $<1200 / \mathrm{mL} 20$ orang (91\%) dan TLC $\geq$ $1200 / \mathrm{mL} 2$ orang (9\%). Sejumlah 14 (63\%) sampel menderita anemia dan 11 (50\%) sampel mempunyai IMT $<18,5 \mathrm{~kg} / \mathrm{m}^{2}$. Terdapat beberapa infeksi oportunistik yang didapatkan pada penderita HIV dalam penelitian ini antara lain kandidiasis pada 13 penderita (59\%), TB pada 9 penderita ( $40 \%)$, kandidiasis dan TB pada 5 penderita ( 22 $\%)$, toksoplasmosis serebri pada 1 penderita (5\%), hepatitis B pada 1 penderita (5\%) dan hepatitis C pada 1 penderita (5\%).

\section{Perubahan Parameter Terapi ARV Sesudah 3 Bulan}

Hasil uji Wilcoxon menunjukkan rerata nilai hitung limfosit T-CD4 absolut pada penderita HIV setelah tiga bulan mendapat terapi ARV lebih tinggi $(180,72 \pm 73,15 \mathrm{sel} / \mu \mathrm{L})$ secara bermakna $(0<0,001)$ dibandingkan sebelum terapi $(69,41 \pm 95,06 \mathrm{sel} / \mu \mathrm{L})$. Uji korelasi Spearman menunjukkan kadar serum IL-17 tidak berkorelasi bermakna terhadap nilai hitung limfosit T-CD4 ( $p=0,914, r=-0,024)$.

Didapatkan hasil rerata kadar IL-17 serum pada penderita HIV setelah 3 bulan mendapat terapi ARV lebih tinggi $(52,91 \pm 9,90 \mathrm{pg} / \mathrm{mL})$ dibandingkan dengan penderita HIV sebelum terapi $(44,17 \pm 12,56 \mathrm{pg} / \mathrm{mL})$. Uji $t$ menunjukkan bahwa perbedan kadar serum IL-17 tersebut bermakna $(p=0,005)$.

Hasil analisa uji beda mendapatkan kadar limfosit T-CD4 $(p=0,000)$, interleukin $17(p=0,005), \operatorname{TLC}(p=0,003), \mathrm{Hb}$ $(p=0,006)$ dan IMT $(p=0,000)$ lebih tinggi secara signifikan dibandingkan sebelum ARV. Tidak ditemukan perbedaan bermakna kadar albumin $(p=0,07)$ sesudah ARV (Tabel 2$)$.

Tabel 2. Perubahan parameter sesudah ARV

\begin{tabular}{lllc}
\hline Variabel (mean \pm SD) & Pre ARV & Post ARV & p \\
\hline CD4 & $69,41 \pm 95,06$ & $180,72 \pm 73,15$ & $0,000^{*}$ \\
Interleukin 17 & $44,17 \pm 12,56$ & $52,91 \pm 9,90$ & $0,005^{*}$ \\
Total Lymphocyte & $828,18 \pm 378,40$ & $1279,54 \pm 495,09$ & $0,04^{*}$ \\
Count (sel/mL) & & & \\
Hemoglobin (g/dL) & $10,65 \pm 2,09$ & $12,07 \pm 1,98$ & $0,006^{*}$ \\
IMT (kg/m²) & $18,16 \pm 2,87$ & $19,95 \pm 2,81$ & $0,000^{*}$ \\
Albumin (g/dL) & $3,35 \pm 0,75$ & $3,55 \pm 0,49$ & 0,07 \\
\hline
\end{tabular}

Keterangan: ${ }^{*}=$ berbeda bermakna $(p<0,05, \alpha=0,05)$ antara kelompok pre dan post terapi ARV

\section{DISKUSI}

\section{Karakteristik Penderita HIV}

Dari penelitian ini diperoleh data bahwa perbandingan penderita HIV pria dan wanita hampir sama (1,2:1), dengan kelompok umur terbanyak adalah 21-30 tahun dan 31-40 tahun. Temuan ini sama dengan penelitian epidemiologis HIV yang menunjukkan bahwa, tidak ada perbedaan signifikan jenis kelamin pria dan wanita (15). Data menunjukkan lebih dari 50\% infeksi HIV terjadi pada penderita yang berusia kurang dari 25 tahun. Lembaga UNAIDS (2008) menerbitkan penelitian yang menyatakan bahwa setiap hari terdapat 7000 remaja antara 10-24 tahun atau lima orang remaja setiap menit yang terinfeksi HIV. Jumlah remaja di negara berkembang sekitar $30 \%$ dari jumlah penduduk, sehingga kelompok remaja rentan terhadap infeksi HIV (16).

Faktor risiko HIV terbanyak pada penelitian ini adalah hubungan seksual, diikuti dengan pengguna narkotika secara intra vena, hasil ini hampir sama dengan hasil penelitian secara nasionaL (15). Berbagai faktor ikut berperan dalam peningkatan kejadian dan kematian akibat infeksi HIV, salah satu faktor yang menonjol adalah perubahan gaya hidup dan perilaku pada individu dan masyarakat. Faktor perubahan perilaku ini berperan besar sehingga bila perubahan perilaku yang tidak sehat ini tetap dibiarkan infeksi HIV tidak dapat dihindarkan (17).

Penelitian ini juga menunjukkan bahwa sebagian besar penderita HIV terdiagnosa pada stadium klinis III (64\%). Pada stadium tersebut penderita sudah dalam kondisi lemah, yang sebagian besar memerlukan perawatan di rumah sakit. Jumlah limfosit T-CD4 saat terdiagnosa $\leq 350$ $\mathrm{sel} / \mu \mathrm{L}$ pada semua penderita, menunjukkan bahwa penderita sudah masuk dalam fase infeksi laten dari perjalanan infeksi HIV. Pada fase ini jumlah limfosit T-CD4 menurun hingga menjadi $500-200 \mathrm{sel} / \mathrm{mm}^{3}$,yang merupakan tanda awal mudahnya terjadi infeksi oportunistik (18). Terdapat beberapa infeksi oportunistik pada penelitian ini antara lain kandidiasis pada 13 (59\%) penderita sebagai infeksi oportunistik terbanyak, serupa dengan data secara nasional. Infeksi opportunistik terbanyak berikutnya pada subjek penelitian ini adalah tuberkulosis yang diderita oleh 9 (40\%) penderita. Hal ini juga sesuai dengan data departemen kesehatan RI tahun 2011, yang menyatakan bahwa TB merupakan infeksi oportunistik terbanyak kedua setelah kandidiasis (15). Data UNAIDS 2010 memaparkan data bahwa pada tahun 2010 didapatkan 1,2 juta kasus TB baru pada penderita HIV dan TB telah menyebabkan 350 ribu kematian penderita HIV. Data UNAIDS 2006 telah menyebutkan bahwa TB memiliki dampak yang lebih besar terhadap morbiditas dan kematian pada individu yang terinfeksi HIV daripada semua infeksi oportunistik lain $(1,19)$. Infeksi oportunistik yang lain pada penelitian ini adalah toksoplasmosis, hepatitis B dan hepatitis C yang didapatkan dalam proporsi penderita yang sama yaitu 1 (5\%) penderita $(1,19)$.

\section{Efek Terapi ARV pada TLC, Hemoglobin, IMT, Albumin}

Penelitian ini menunjukkan bahwa total lymphocyte count (TLC) berbeda secara bermakna sesudah mendapat terapi ARV. Jumlah TLC yang rendah pada penelitian sebelumnya dapat dipakai sebagai penanda fungsi imunitas dan berhubungan dengan stadium klinis walaupun WHO saat ini telah menyarankan untuk meninggalkan pemeriksaan TLC karena rendahnya sensitivitas dan spesifisitas TLC sebagai marker pengganti dari limfosit T-CD4 dan tidak dianjurkan untuk menilai respon terapi ARV atau sebagai dasar dalam menentukan kegagalan terapi ARV $(13,14,20)$.

Kadar $\mathrm{Hb}$ penderita HIV pada penelitian ini, menunjukkan bahwa terdapat perbedaan yang bermakna sesudah mendapat terapi ARV. Beberapa studi menunjukkan bahwa anemia adalah komplikasi yang sering terjadi (20$80 \%$ ) pada penderita HIV, berhubungan dengan kecepatan progresivitas penyakit, mortalitas dan faktor prognostik pada infeksi HIV (21-23). Infeksi HIV dapat menyebabkan anemia melalui beberapa mekanisme, antara lain perubahan produksi sitokin yang berhubungan dengan $\mathrm{Hb}$, 
penurunan eritropoietin, adanya infeksi oportunistik seperti Mycobacterium avium complex, M. tuberculosis dan parvovirus, pemberian ARV seperti zidovudin, defisiensi vitamin B12 dan proses autoimun (22-26).

Penelitian ini juga menunjukkan bahwa indeks massa tubuh (IMT) sesudah mendapat terapi ARV berbeda secara bermakna. Pengukuran IMT adalah sederhana dan sering digunakan untuk mengukur status nutrisi penderita HIV, baseline IMT $<18,5 \mathrm{~kg} / \mathrm{m}^{2}$ berhubungan dengan peningkatan mortalitas penderita HIV dan meningkatkan resiko 2-5 kali lipat untuk menjadi AIDS walaupun sensitivitasnya hanya 33\% (23,27-29).

Dari pemeriksaan kadar albumin yang dilakukan diketahui bahwa ada peningkatan kadar albumin setelah mendapat terapi ARV, walaupun peningkatan tersebut tidak bermakna secara signifikan. Penelitian yang dilakukan oleh Koethe dkk di Zambia, sub Sahara, Afrika menunjukkan bahwa rendahnya kadar albumin pada baseline, sebelum terapi ARV, berhubungan dengan mortalitas dalam 12 minggu saat mendapat terapi ARV. Penurunan kadar albumin serum pada penderita HIV dapat terjadi karena peningkatan sitokin inflamasi yang menghambat sintesa protein dan kurang adekuatnya intake nutrisi $(23,30-32)$.

\section{Efek Terapi ARV pada Kadar IL-17 dan CD4}

Virus HIV akan merusak limfosit T, karena pada limfosit $T$ terdapat reseptor limfosit T-CD4, reseptor untuk melekatnya virus HIV ke permukaan limfosit $T(17,18)$. Dalam penelitian ini dibuktikan bahwa jumlah limfosit TCD4 penderita HIV mengalami penurunan secara signifikan. Penurunan jumlah limfosit T-CD4 ini menyebabkan terjadinya immunodefisiensi secara progresif sehingga membuka kemungkinan terjadinya infeksi oportunistik $(18,23,33,34)$. Penderita HIV pada penelitian ini didapatkan dengan infeksi oportunistik seperti kandidiasis, TB, toksoplasmosis, hepatitis B dan hepatitis $\mathrm{C}$.

Sitokoin IL-17 yang dihasilkan oleh sel Th-17 pada penelitian ini terbukti secara signifikan kadarnya lebih tinggi setelah mendapat terapi ARV, hasil ini sama dengan penelitian yang dilakukan oleh $\mathrm{He} \mathrm{Y}$ et al. Rendahnya rerata kadar IL-17 sebelum mendapat terapi ARV ini dapat merefleksikan penurunan sel Th17, yang dari beberapa penelitian disebutkan bahwa terdapat korelasi positip antara IL-17 plasma dengan persentase sel Th-17 dan berkorelasi negatif dengan viral load penderita $\operatorname{HIV}(2,7)$. Berkurangnya Th-17 dapat disebabkan oleh destruksi langsung oleh virus HIV terhadap sel Th-17 ataupun juga mekanisme non viral seperti perubahan lingkungan sitokin $(2,7)$. Penurunan IL-17 menyebabkan berkurangnya kemampuan sel host untuk melawan bakteri, meningkatkan kerusakan mukosa barier, peningkatan replikasi virus dan peningkatan hilangnya

\section{DAFTAR PUSTAKA}

1. UNAIDS. Global Report, UNAIDS Report on The Global AIDS Epidemic. Geneva: WHO; 2010; p. 16-62.

2. He Y, Li J, Zheng Y, et al. A Randomized Case-Control Study of Dynamic Changesin Peripheral Blood Th17/Treg Cell Balance and Interleukin-17 Levels in Highly Active Antiretroviral-Treated HIV Type 1/AIDS Patients. AIDS Research and Human Retroviruses.
Th17 dan limfosit T-CD4 mengikuti kerusakan sistem imun $(35,36)$

Penelitian ini membuktikan bahwa penderita HIV yang telah memperoleh terapi ARV mempunyai kadar rerata IL17 dan limfosit T-CD4 yang meningkat secara signifikan dibanding sebelum terapi ARV. Hasil ini sesuai dengan beberapa penelitian yang pernah dilakukan. Terapi ARV dapat menekan replikasi virus HIV, menurunkan viral load, mencegah perburukan tanda dan gejala infeksi HIV, memperlambat progresivitas penyakit, menurunkan kejadian infeksi oportunistik, melindungi limfosit T-CD4 dari kerusakan dan secara bertahap dapat memperbaiki sistem imun $(13,14)$. Terapi ARV dapat menurunkan viral load dengan mengurangi kerusakan langsung Th-17 oleh virus HIV. Pada infeksi HIV terjadi peningkatan CD8, CD8 sitolitik ini dapat merusak sel Th-17 yang terinfeksi virus HIV $(2,26,27)$. Terapi ARV ini dapat mengurangi CD8 sehingga terjadi perbaikan sel Th-17. Terapi ARV juga dapat mengubah lingkungan seluler untuk mendukung diferensiasi Limfosit T-CD4 menjadi sel Th-17 dan menghambat pembentukan $T$-reg $(2,26)$.

Telah dibuktikan bahwa penderita HIV yang memperoleh terapi ARV mempunyai kadar rerata IL-17 dan limfosit TCD4 yang meningkat secara signifikan dibanding sebelum terapi. Penelitian yang dilakukan oleh Prendergast et al dan He $\mathrm{Y}$ et al melaporkan bahwa kadar IL-17 serum berkorelasi positif dengan Th-17 dan kadar Th-17 berkorelasi positif dengan jumlah limfosit T-CD4, tetapi tidak menyebutkan hubungan antara kadar IL-17 dengan jumlah limfosit T-CD4 (2,35). Beberapa sel imun diketahui dapat mensekresikan IL-17, seperti sel $\gamma \delta T$, sel natural killer (NK), sel lymphoid-tissue induced (LTi)-like, sel CD8, dan sel myeloid $(10,11)$. Sel-sel imun yang dapat memproduksi IL-17 terdiri dari sel T memori serta sel imun innate, sehingga dapat mendukung fungsi IL-17 sebagai penghubung antara sistem imun inate dengan adaptif, melalui induksi dan rekrutmen neutrofil. Hasil yang didapatkan menujukkan bahwa kadar serum IL-17 tidak berhubungan secara signifikan dengan hitung limfosit TCD4 absolut. Hasil ini menguatkan penelitian yang menyatakan bahwa IL-17 tidak hanya diproduksi oleh sel Th-17 yang berasal dari sel limfosit T-CD4 saja. Penelitian ini hanya memeriksa jumlah total limfosit T-CD4, tidak secara spesifik memeriksa Th-17, dan T-reg, sehingga tidak dapat menggambarkan fungsi Th-17 dan T-reg. Standar deviasi yang besar pada kadar serum IL-17 dan hitung limfosit T-CD4 juga dapat mempengaruhi tidak adanya hubungan kedua variabel tersebut.

Dapat disimpulkan bahwa sesudah terapi ARV tiga bulan kadar IL-17 serum dan limfosit T-CD4 penderita infeksi HIV lebih tinggi dibandingkan sebelum mendapat terapi ARV meskipun tidak didapatkan korelasi signifikan antara kadar IL-17 serum dengan hitung sel limfosit T-CD4.

2012; 28(4):339-345.

3. Lim A, Tan D, Price P, et al. Proportions of Circulating T Cells with a Regulatory Cell Phenotype Increase with HIV-Associated Immune Activation and Remain High on Antiretroviral Therapy. AIDS. 2007; 21(12): 1525-1534.

4. Mason RD, De Rose R, and Kent SJ : CD4 + T-cell Subsets: What Really Counts in Preventing HIV 
Disease? Expert Review of Vaccines. 2008; 7(2): 155-158.

5. Curtis MM and Way SS. IL-17 in Host Defense Againts Bacterial, Myobacterial and Fungal Pathogens. Cellular \& Molecular Immunology. 2008; 126: 177-85.

6. Miossec $\mathrm{P}$, Korn T, and Kuchroo VK. Interleukin 17 and Type 17 Helper $T$ Cells. The New England Journal of Medicine. 2009; 361(9): 888-898.

7. Klatt NR and Brenchley JM. Th 17 Cell Dynamics in HIV Infection. Current Opinion in HIV and AIDS. 2010; 5(2): 135-140.

8. Milner JD, Sandler NG, and Douek DC. Th17 cells, Job Syndrome and HIV: Opportunities For Bacterial And Fungal Infections. Current Opinion in HIV and AIDS. 2010; 5(2): 179-183.

9. Eyerich K, Foerster S, Rombold S, et al. Patients with Chronic Mucocutaneous Candidiasis Exhibit Reduced Production of Th17-Associated Cytokines IL-17 and IL22. Journal of Investigative Dermatology. 2008; 128(11): 2640-2645.

10. Guglani L and Khader SA. Th17 Cytokines in Mucosal Immunity and Inflammation. Current Opinion in HIV and AIDS. 2010; 5(2): 120-127.

11. Elhed A and Unutmaz D. Th 17 Cells and HIV Infection. Current Opinion in HIV and AIDS. 2010; 5: 146-150.

12. Dandekar S, George MD, and Bumler AJ. Th17 Cells, HIV and the Gut Mucosal Barrier. Current Opinion in HIV and AIDS. 2010; 5(2): 173-178.

13. Grulich AE. Cancer: The Effects of HIV and Antiretroviral Therapy, and Implications for Early Antiretroviral Therapy Initiation. Current Opinion in HIV and AIDS. 2009; 4(3): 183-187.

14. Onishi RM and Gaffen SL. Interleukin 17 and its Target Genes: Mechanisms of Interleukin 17 Function in Diseases. Cellular \& Molecular Immunology. 2010; 129(3): 311-321.

15. Kementerian Kesehatan RI. Laporan Situasi Perkembangan HIV \& AIDS di Indonesia. Jakarta: Kementerian Kesehatan RI; 2011.

16. World Health Organization. Guidelines for Diagnostic and Monitoring of Antiretroviral Therapy. New Delhi: WHO; 2005.

17. Nasronudin. Patofisiologi Infeksi HIV. Di dalam: Barakbah J, Soewandojo E, Suharto, Hadi U, dan Astuti WD (Eds). HIV \& AIDS, Pendekatan Biologi Molekuler, Klinis dan Sosial. Surabaya: Airlangga University Press; 2007; p. 19-26.

18. Fauci AS and Lane HC. Human Imunodeficiency Virus Disease: AIDS and Related Disorders. In: Fauci AS, Kasper DL, Longo DL, Braunwald E, and Hauser SL (Eds). Harrisons Principle of Internal Medicine 17th edition. New York: McGraw Hill; 2007; p. 1137-1204.

19. Astari L, Sawitri, Safitri YE, dan Hinda DP. Viral Load pada infeksi HIV. Berkala IImu Kesehatan Kulit \& Kelamin. 2009; 21(1): 31-39.

20. Langford SE, Ananworanich J, and Cooper DA. Predictors of Disease Progression in HIV Infection: A Review. AIDS Research and Therapy. 2007; 4: 11.
21. Widodo ADW dan Lusida MI. Biologi Molekuler HIV. Di dalam: Nasronudin, Hadi U, Vitanata, Bramantono, dan Suharto (Eds). Penyakit Infeksi di Indonesia. Surabaya: Airlangga University Press; 2007; p. 22-28.

22. Obirikorang $\mathrm{C}$ and Yeboah FA. Blood Haemoglobin Measurement as a Predictive Indicator for the Progression of HIV/AIDS in Resource-Limited Setting. Journal of Biomedical Science. 2009; 16(1): 102.

23. Zauli G, Re MC, Visani G, Furlini G, Mazza P, Vignoli M, and LaPlaca M. Evidence for a Human Immunodeficiency Virus Type-1 Mediated Suppression of Uninfected Hematopoietic (CD341) Cells in AIDS Patients. The Journal of Infectious Diseases. 1992; 166(4): 710-716.

24. Maciejewski JP, Weichold FF, and Young NS. HIV-1 Suppression of Hematopoiesis In Vitro Mediated by Envelope Glycoprotein and TNF-a. The Journal of Immunology. 1994; 153: 4303-4310.

25. Spivak JL, Barnes DC, Fuchs E, and Quinn TC. Serum Immunoreactive Erythropoietin in HIV-Infected Patients. JAMA The Journal of the American Medical Association. 1989, 261(2): 3104-3107.

26. Remacha AF, Riera A, Cadafalch J, and Gimferrer E. Vitamin B-12 Abnormalities in HIV-Infected Patients. European Journal of Haematology. 1991, 47(1): 60-64.

27. Maas JJ, Dukers N, Krol A, et al. Body Mass Index Course in Asymptomatic HIV-Infected Homosexual Men and the Predictive Value of a Decrease of Body Mass Index for Progression to AIDS. Journal of Acquired Immune Deficiency Syndromes and Human Retrovirology. 1998, 19(3):254-259.

28. Castetbon K, Anglaret X, Toure S, et al. Prognostic Value of Cross-Sectional Anthropometric Indices on Short-Term Risk of Mortality in Human Immunodeficiency Virus-Infected Adults in Abidjan, Cote d'Ivoire. American Journal of Epidemiology. 2001; 154(1): 75-84.

29. Thiebaut R, Malvy D, Marimoutou C, and Dabis F. Anthropometric Indices as Predictors of Survival in AIDS Adults. Aquitaine Cohort, France, 1985-1997. European Journal of Epidemiology. 2000; 16(7): 633639.

30. Dusingize JC, Hoover DR, Shi Q, Mutimura E, Kiefer E, Cohen M, Anastos K. Association of Serum Albumin with Markers of Nutritional Status among HIVInfected and Uninfected Rwandan Women. PloS One. 2012; 7(4): e35079.

31. Jensen GL, Bistrian B, Roubenoff R, and Heimburger DC. Malnutrition Syndromes: A Conundrum vs Continuum. Journal of Parenteral and Enteral Nutrition. 2009; 33(6): 710-716.

32. Zachariah R, Fitzgerald M, Massaquoi M, et al. Risk Factors for High Early Mortality in Patients on Antiretroviral Treatment in a Rural District of Malawi. AIDS. 2006; 20(18): 2355-2360.

33. Oswald-Richter K, Grill SM, Shariat N, et al. HIV Infection of Naturally Occurring and Genetically Reprogrammed Human Regulatory T-Cells. PLoS Biology. 2004; 2(7): E198.

34. Eggena MP, Barugahare B, Jones N, et al. Depletion Of 
Regulatory T Cells In HIV Infection Is Associated With Immune Activation. The Journal of Immunology. $2005 ; 174(7)$ : 4407-4414.

35. Prendergast A, Prado JG, Kang $\mathrm{YH}$, et al. HIV-1 Infection is Characterized by Profound Depletion of
CD161 + Th17 Cells and Gradual Decline in Regulatory TCells. AIDS. 2010; 24(4): 491-502.

36. Kanwar B, Favre D, and McCune JM. Th17 and Regulatory T cells: Implications for AIDS Pathogenesis. Current Opinion in HIV and AIDS. 2010;5:151-157. 